\title{
Climate Change Impacts on Agriculture, a Case Study of Bangladesh, India, Nepal, and Pakistan
}

\author{
https://doi.org/10.21272/sec.5(2).35-48.2021
}

Medani P. Bhandari, PhD, ORCID: https://orcid.org/0000-0003-2213-2349

$\mathrm{PhD}$, Professor, Department of Natural Resource \& Environment / Sustainability Studies, Akamai University, USA; Professor, Department of Finance and Entrepreneurship, Sumy State University, Ukraine

\begin{abstract}
Climate change raises the risk on food security, alters the cropping pattern, and secondly, it also plays the triggering role to widen inequality. The South Asian region is home to nearly half of the poor and malnourished population of the world. In South Asia - Bangladesh, India, Nepal, and Pakistan encounter similar climate induced changes though they differ in their socio-political, economic, and cultural conditions. The physiological population densities (farming population per unit of agricultural land) suggest that these countries belong to the threat zone in terms of climate change impact on agriculture. It has been obvious that any unfavorable climatic conditions mean poor agricultural growth which will have serious ramification on the countries' economies. Poverty induces poverty; because of the rudimentary technologies used in agriculture, more manpower is needed for farming thus encouraging couples to increase family manpower to invest on farming, which might lead to overpopulation. This paper evaluates how climate change has direct impact on the agricultural development and broader economic growth in the global context and South Asia (Bangladesh, India, Nepal, and Pakistan). Paper unveils the climate change induced challenges in agriculture with the empirical evidence, elaborates the consequences to the farmers livelihood and food security. Based on secondary information, this paper provides climate change risk scenario and recommends few coping strategies to minimize the climate change impact in farming systems and pathway for the future research.
\end{abstract}

Keywords: South Asia, Bangladesh, India, Nepal, Pakistan, Agriculture, Food Security, Food Insecurity, Climate Change, Subsistence Farming, Livelihood, Coping Strategies.

JEL Classification: Q1, Q10, Q18.

Cite as: Bhandari, M.P. (2021). Climate Change Impacts on Agriculture, a Case Study of Bangladesh, India, Nepal, and Pakistan. SocioEconomic Challenges, 5(2), 35-48. https://doi.org/10.21272/sec.5(2).35-48.2021.

Received: 28.04 .2021

Accepted: 29.05 .2021

Published: 25.06 .2021

Copyright: (C) 2021 by the author. Licensee Sumy State University, Ukraine. This article is an open access article distributed under the terms and conditions of the Creative Commons Attribution (CC BY) license (https://creativecommons.org/licenses/by/4.0/).

\section{Introduction}

To examine the relationships between food security, the food system, and climate change, there are many academic and institutional research and reports which directly or indirectly address the on the issues of climate change and agriculture (IPCC 1990; 2007, 2014, 2018; FAO 2015, 2019; UNEP 2019; UNFCCC 2007; UNICEF 2018; UN Women 2020; United Nations 2015; World Bank Data 2011; WFP and FAO 2007; Germanwatch2020; The Consultative Group on International Agricultural Research-CGIAR 2011; WDI 2014; WMO 2017 and so on). "Indeed, climate change is a complex challenge that poses a major threat to our planet and life, as we know it. Over time, many scientific uncertainties about climate change - its causes and global implications -have been

\footnotetext{
${ }^{1}$ I would like to declare that the small part of this paper was published in - Acta Scientific Agriculture 2.8 (2018). With titled "Climate Change Impacts on Food Security, a Brief Comparative Case Study of Bangladesh, India, Nepal and Pakistan". Copyright Cbhandari.
} 
addressed and the evidence continues to mount. Today, we know that increasing temperatures, ocean warming and acidification, severe droughts and wildfires, untimely heavy precipitation, and acid rain, melting glaciers and rising sea levels and amplification of extreme weather events are causing unprecedented damage to our food systems. Even a single environmental driver like rising temperatures can have varying degrees of effect across multiple food safety hazards, simultaneously, around the world, with subsequent impacts on public health and international trade" (FAO 2020:xiii).

The individual or group of scholars also conclude the similar results on climate change induced challenges in agriculture sector, as shown in above text boxes (Cruz et. al. 2007; Sivakumar and Stefanski 2011; Ortiz et. al. 2008; Vinke et. al. 2017; Aryal et. al..2020; Pandey et. al.2016; Parry 1990; Petit et. al 1999; Rasul et. al.2019; Raut 2006; Shakya et.al 2013; Shrestha and Nepal 2016; Tiwari and Joshi 2012). In addition, to these, there are hundreds and hundreds of country specific case studies, which exhibit the climate change induced problems on agriculture, which covers both developed and developing world, including South Asia (India, Nepal, Bangladesh, and Pakistan) (Bhandari 2020).

\section{The South Asian Context}

The South Asian region is home to nearly half of the poor and malnourished population of the world. In this region, food insecurity is high, with almost $23 \%$ of the population not having access to adequate calorie intake (WDI, 2014). Agriculture is the main source of livelihood as it employs 60\% of the total workforce (FAO, 2013) (as cited in Pandey et al 2016:28). However, due to climate change induced problem the agriculture pattern is altered which has raised a severe challenge to the farmers (mostly to the small formers) (Bhandari et al 1999; Bhandari 2012).

In South Asia-Bangladesh, India, Nepal, and Pakistan encounter similar climate induced changes though they differ in their socio-political, economic, and cultural conditions. The majority of the people of this region still live on subsistence farming, for example, $73 \%$ population in Bangladesh lives on subsistence farming, $71 \%$ in India, $83 \%$ in Nepal, and 64\% in Pakistan (World Bank, 2011). The physiological population densities (farming population per unit of agricultural land) suggest that these countries belong to the threat zone in terms of climate change impact on agriculture. It has been obvious that any unfavorable climatic conditions mean poor agricultural growth which will have serious ramification on the countries' economies. Poverty induces poverty; because of the rudimentary technologies used in agriculture, more manpower is needed for farming thus encouraging couples to increase family manpower to invest on farming, which might lead to overpopulation. Nepal's condition is the most vulnerable due to her over dependence on monsoon climate (Bhandari, 2012, 2018). The high physiological population density of Nepal indicates maximum vulnerability to food security, if any unprecedented climatic variation occurs.

The scenarios of the country in terms of population growth and density are changed and increased substantially, however, the arable land is decreased, percentage of cropland is decreased; and in some cases, the cereal / the crop production is also increased, however, the problems of food security have been constantly increasing. The farmers are not being able to cope with the climatic variation because of the climate change. The subsistence farmers are the main victims of global warming. There are stories of farmers suicides (India, Bangladesh, Nepal, Pakistan), because they are not being able to pay the loan to the bank, which they have to take to invest in crop production. The irregularity in rain pattern, drought, flood and unseasonal rain or drought have changed the agriculture production pattern.

The peripheral status of Nepal, India, Bangladesh and Pakistan and the over dependence of increasing population on limited subsistence practices have created various vicious cycles. In these countries, have been already facing food security problems and will experience even greater challenges due to convergence of multiple factors. For example, in the Nepal case, on the demand side, population will increase from estimated 28.8 million today to nearly 36.2 million by 2025 (Population Reference Bureau, 2010). Already, agricultural production and food security have been hampered due to increasing land degradation, lack of location-specific technology, and inadequate infrastructure for agricultural development (Pyakuryal et al., 2010; Shrestha and Bhattarai, 2003). In addition to poor technological responses to agriculture, the ongoing political instability has not only threatened the subsistence farming economies (Upreti et al. , 2010) but also it has forced many agricultural workers to migrate abroad hoping for remittances (Ghimire and Upreti, 2010). 
Food market has been very instable due to the decrease in farm production (Pyakuryal and Upreti, 2010; Thapa, 2010). Intertwined effects of these factors have posed significant challenges to farm communities (Pyakuryal and Upreti, 2010). In some areas farm produces such as apples, peaches, and vegetables are decayed on the fields due to unprecedented bands (shutdown) of transportation (Adhikari, 2008). Many patients have died unexpectedly due to the shutdown of transportation services. Poor government responses to increasing insecurity have created difficult lives (BBC, Nepali Service). Coupled to these problems, climate changes and associated variability have threatened agricultural production. To improve our understanding of the great uncertainty of agricultural production coupled with the large potential impacts of increased population mobility, it has been essential to increase our understanding of the relationship between climate variability and change and human behaviors such as migration (Axinn and Ghimire, 2007; Brown, 2008; Carr, 2009; (Bhandari et al., 1999; Bhandari, 2012). Though much research has focused on forced migration due to political uncertainties, little is known regarding the indirect impacts of climate on human migration leaving aside the farming practices. To address the deficiency, there is need to investigate the impact of climatic vulnerability on the food security of people. "Vulnerability to climate change refers to the propensity of human and ecological systems to suffer harm and their ability to respond to stresses imposed because of climate change effects. The vulnerability of a society is influenced by its development path, physical exposures, the distribution of resources, prior stresses and social and government institutions... Adaptation to climate change takes place through adjustments to reduce vulnerability or enhance resilience in response to observed or expected changes in climate and associated extreme weather events" (Adger et al., 2007:720). Nepali people have managed to adapt in different circumstances, for example, even though the winter drought of 2008/2009 had almost decimated the winter crops throughout the country (MoAC/WFP/FAO, 2009), people of Nepal have survived by diversifying their farming activities, such as planting fruit trees or focusing more on animal husbandry (Bhattarai, 2010). In the same year, despite a strong harvest of summer crops, net harvest resulted in a negative production balance of 132,914 MT of cereal (-2.5\%) for all of Nepal (CBS, 2009). With ever increasing population, even a slight decrease in annual food production becomes a matter of great concern for food security. Because of these vulnerabilities, people might not have enough food even to purchase as Amartya Sen puts food security toward the demand side (Coates et al., 2006; Webb et al, 2006; Feleke et al., 2005). In a subsistence farming, a shortage of food leads to environmental degradation that threatens food security. Increasing food insecurity leads to the deterioration of ecological services, which in turn creates further food shortages (Bhattarai, 2010). According to the FAO (2009), in 2008-09, there was a total of 132,916 metric tons food grain deficit in Nepal that impacted $16 \%$ of 28 million populations across the country. Mountains and hill regions face such vulnerabilities more frequently than the Tarai region (Ghale, 2010). Districts located in the western regions are the most vulnerable. Disaster, mostly natural ones, are the major causes of instability in food production in which substantial land area, crops, livestock, and human losses incur every year (Bhandari 2011). Drought and landslide have impacted on the production of paddy, maize and millet. In 2008/09, the total cropped area affected by natural disasters was 93,700 hectares in which paddy area was 92,000 hectares (Pyakuryal and Upreti, 2010).

\subsection{Food security and climate change}

Food security has been understood in different forms, and very often, it has been defined narrowly to mean food self-sufficiency, but it is much more than this. The FAO defines food security as a state "when all people, at all times, have physical and economic access to sufficient, safe and nutritious food to meet their dietary needs and food preferences for active and healthy life." This definition encompasses several dimensions of food security. First, it implies both physical and economic access to sufficient food. Second, it means that such access should encompass all people irrespective of their economic and social backgrounds. Third, it always implies such access in a year, and in times of unusual events such as that prompted by social unrest and climatic factors. Fourth, it implies that food has to be safe, nutritious and conducive to a healthy life. Of the several dimensions of food security, in the case of Nepal, net productivity of grains has the most direct effect on food security. Understanding the potential impact of climate change on food security in Nepal is critical for two reasons. First, the existing system of food production in the country is highly climate sensitive because of its low level of capital and technology. Second, agriculture is the main source of livelihood for the $88 \%$ of the total population in Nepal, where $80 \%$ of over 15 years population is engaged in agriculture (NG/ADB, 1995). Nearly $2 / 3^{\text {rd }}$ of the rural household income is derived from agricultural activities, and 8 out of 10 people working in the agriculture sector are self-employed farmers. This is the only source of cash income for $90 \%$ poor people (Ghale, 2010). The 
consequences of an adverse climate change could therefore significantly affect food security of the country and the well-being of the Nepalese people (Chhetri, 2008). Any decrease in food production will further reduce the food intake in this one of the poorest calories in-take countries of the world. Like the global trends, evidence of climate change, such as general warming, receding snowline, prolonged drought, and unpredictable rainfall patterns, have been well documented across the country (MoE, 2010). BBC Nepali news often presents discussions on the issues of changing farming practices and phonological patterns in the hills of Nepal where temperature is increasing from 0.06 to $0.12^{\circ} \mathrm{C}$ year in recent decades, with significant warming in the higher elevations of the Hills and Mountain. In the high-altitude region of Nepal, there are also reports of the loss of arable land due to drying of irrigation canals fed by melting snow but no longer replenishment with receding snowline. A recent assessment of the change in average temperature and precipitation in Nepal using over a dozen general circulation models (GCMs) projected a significant change in rainfall and consistent increase in temperatures for 2030, 2050, and 2100 (Agrawala, et al., 2003). Characterized by low levels of capital and technology, Nepal's existing system of food production is highly climate sensitive and is considerably more vulnerable to climate change (Chhetri, 2008).

\subsection{Why South Asia is vulnerable to climate change}

"South Asia is home to over one fifth of the world's population and is known to be the most disaster-prone region in the world. The high rates of population growth, and natural resource degradation, with continuing high rates of poverty and food insecurity make South Asia one of the most vulnerable regions to the impacts of climate change"... "South Asia is one of the most vulnerable regions in the world to climate change in view of the huge population, the large number of poor facing food insecurity, inappropriate soil and management practices on marginal lands in the semi-arid regions leading to increasing rates of land degradation and the projected impacts of climate change on the agricultural, forestry and fisheries sectors" (Sivakumar and Stefanski 2011:13 and 27). The geographic condition- mountain, terrain - the Hindukush Himalaya, the Bay of Bengal, the rivers systemsthe population and the impact on natural ecosystem primarily in the process of survive and unplanned development scenarios help South Asia towards the venerability to changing climatic pattern. "Mountain people in the Hindu-Kush Himalayan region encompassing parts of Pakistan, India, Nepal, and China, are particularly vulnerable to food insecurity related to climate change because of poor infrastructure, limited access to global markets, physical isolation, low productivity, and hazard exposure, including Glacial Lake Outburst Floods (GLOFs) (Rasul et al., 2019; Rasul, 2010; Tiwari and Joshi, 2012; Huddleston et al., 2003; FAO, 2008; Nautiyal et al., 2007). Surveys have been conducted to determine how climate-related changes have affected food security (Hussain et al., 2016; Shrestha and Nepal, 2016) with results showing that the region is experiencing an increase in extremes, with farmers facing more frequent floods as well as prolonged droughts with ensuing negative impacts on agricultural yields and increases in food insecurity (Hussain et al., 2016; Manzoor et al., 2013)" (IPCC 2019:452). The table 5, below shows the Climate change pattern in South Asia.

Table 2. Climate change pattern in South Asia

\begin{tabular}{|c|c|c|}
\hline Country & Change in temperature & Change in precipitation \\
\hline Bangladesh & $\begin{array}{c}\text { Increasing trend of about } 1^{\circ} \mathrm{C} \text { in May and } 0.5^{\circ} \mathrm{C} \\
\text { in November from } 1985 \text { to } 1998\end{array}$ & $\begin{array}{l}\text { Decadal rain anomalies above long-term averages since } \\
1960 \mathrm{~s} \\
\end{array}$ \\
\hline India & $\begin{array}{l}0.68^{\circ} \mathrm{C} \text { increase per century with increasing } \\
\text { trends in annual mean temperature and warming } \\
\text { more pronounced during post monsoon and } \\
\text { winter }\end{array}$ & $\begin{array}{c}\text { Increase in extreme rains in northwest during summer } \\
\text { monsoon in recent decades and lower number } \\
\text { of rainy days along east coast. }\end{array}$ \\
\hline Nepal & $\begin{array}{l}0.09^{\circ} \mathrm{C} \text { increase per year in Himalayas and } \\
0.04^{\circ} \mathrm{C} \text { in Terai region with more in winter }\end{array}$ & $\begin{array}{l}\text { No distinct long-term trends in precipitation records for } \\
1948-1994\end{array}$ \\
\hline Pakistan & $\begin{array}{l}0.6-1.0^{\circ} \mathrm{C} \text { increase in mean temperature in } \\
\text { coastal areas since early } 1900 \mathrm{~s}\end{array}$ & $\begin{array}{l}\text { 10-15\% decrease in coastal belt and hyper arid plains and } \\
\text { increase in summer and winter precipitation } \\
\text { over the last } 40 \text { years in northern Pakistan }\end{array}$ \\
\hline Sri Lanka & $\begin{array}{l}0.016^{\circ} \mathrm{C} \text { increase per year between } 1961 \text { to } 90 \\
\text { over entire country and } 2^{\circ} \mathrm{C} \text { increase per year in } \\
\text { central highlands }\end{array}$ & An increase trend in February and decrease trend in June \\
\hline
\end{tabular}


Source: Cruz et al., 2007 as cited in Sivakumar and Stefanski 2011:17- as shown in the table "Asia can be characterized by increasing air temperatures which are more pronounced during winter than in summer. During recent decades, the observed increases in some parts of Asia have ranged between less than $1-3^{\circ} \mathrm{C}$ per century. Across all of Asia, inter seasonal, interannual and spatial variability in rainfall trend has been observed during the past few decades. Decreasing trends in annual mean rainfall have been observed in the coastal belts and arid plains of Pakistan and parts of North-East India with increasing trends in Bangladesh" (Sivakumar and Stefanski 2011:17). Similarly, Aryal et al (2020), note that "In South Asia (SA), it is predicted that the annual average maximum temperature may increase by $1.4-1.8^{\circ} \mathrm{C}$ in 2030 and $2.1-2.6^{\circ} \mathrm{C}$ in 2050 , and thus, heat-stressed areas in the region could increase by $12 \%$ in 2030 and $21 \%$ in 2050 (Tesfaye et al. 2017). Projections claim that almost half of the Indo-Gangetic Plains (IGP), the major food basket of the South Asian region, may become inappropriate for wheat production by 2050 because of heat stress (Ortiz et al. 2008). Even a relatively modest warming of $1.5-2{ }^{\circ} \mathrm{C}$ in SA can severely impact the availability and stability of water resources due to increased monsoon variability and glacial meltwater, thereby threatening the future agricultural productions (Vinke et al. 2017).

"In Nepal and Bhutan, melting glaciers are filling glacial lakes beyond their capacities contributing to Glacial Lake Outburst Floods (GLOFs) (UNEP, United Nations Environment Programme 2007). Of 2,323 glacial lakes in Nepal, 20 have been found to be potentially dangerous with respect to GLOFs. The most significant such event occurred in 1985, when a glacial lake outburst flood caused a 10-15 m high surge of water and debris to flood down the Bhote Koshi and Dudh Koshi rivers for $90 \mathrm{~km}$, destroying the Namche Small Hydro Project (Raut 2006)" (Sivakumar and Stefanski 2011:23).

With its impact on agricultural production and natural resources, climate change will bring greater fluctuation in crop production, food supplies, and market prices and will aggravate the situation of food insecurity and poverty in South Asian countries, which adversely affects the livelihoods of millions of people in the region (Schmidhuber and Tubiello 2007; Bandara and Cai et.al., 2014; Aryal et al., 2019b) (as in Aryal et al., 2020: 5046), and IPCC has projected $0.5-1.2^{\circ} \mathrm{C}$ rise in temperature by $2020,0.88-3.16^{\circ} \mathrm{C}$ by 2050 , and $1.56-5.44{ }^{\circ} \mathrm{C}$ by 2080 depending on the scenarios of future development (IPCC 2007a). and the lead author of IPCC- stated in 1990, that South East Asia $\left(5-300 \mathrm{~N}, 70-105^{\circ} \mathrm{E}\right)$-The warming varies from 1 to $2^{\circ} \mathrm{e}$ throughout the year. Precipitation changes little in winter and generally increases throughout the region by 5 to $15 \%$ in summer. Summer soil moisture increases by 5 to $10 \%$. Parry (1990:17).

\section{Climate Risk on Agriculture System}

As noted by FAO, 'at no other point in history has agriculture been faced with such an array of familiar and unfamiliar risks, interacting in a hyperconnected world and a precipitously changing landscape. The growing frequency and intensity of disasters, along with the systemic nature of risk, are jeopardizing our entire food system .... Disasters threaten all three pillars of sustainable development: social, environmental, economic. This is happening more rapidly and unpredictably than anticipated, across multiple sectors, dimensions, and scales. Agriculture continues to bear the brunt of disaster impacts as new risks and correlations emerge (FAO, 2021). According to Climate Risk Index, South Asia has been in high risk due to climate change. Climate Risk Index prepared by Germanwatch (2020); show Pakistan is in fifth, Bangladesh seventh and Nepal nineth most risky countries for climate change. "In India, Pakistan, Nepal and Bangladesh, water shortages have been attributed to rapid urban growth, industrialization, population growth and inefficient water use, which are exacerbated by a changing climate and its negative impacts on water demand, supply, and quality" (Sivakumar and Stefanski 2011:19) (table 6).

Table 3. The Long-Term Climate Risk Index (CRI): The 10 countries most affected from 1999 to 2018 (annual averages) - (Germanwatch, 2020)

\begin{tabular}{|c|c|c|c|c|c|c|c|}
\hline $\begin{array}{c}\text { CRI 1999- } \\
\begin{array}{c}\text { 2018 (1998- } \\
\text { 2017) }\end{array}\end{array}$ & Country & CRI score & Death toll & $\begin{array}{c}\text { Deaths per } \\
100000 \\
\text { inhabitants }\end{array}$ & $\begin{array}{c}\text { Total losses } \\
\text { in million } \\
\text { US\$ PPP }\end{array}$ & $\begin{array}{c}\text { Losses per } \\
\text { unit GDP in } \\
\%\end{array}$ & $\begin{array}{c}\text { Number of } \\
\text { events (total } \\
1999-2018)\end{array}$ \\
\hline $1(1)$ & Puerto Rico & 6.67 & 149.90 & 4.09 & 4567.06 & 3.76 & 25 \\
\hline $2(3)$ & Myanmar & 10.33 & 7052.40 & 14.29 & 1630.06 & 0.83 & 55 \\
\hline $3(4)$ & Haiti & 13.83 & 274.15 & 2.81 & 388.93 & 2.38 & 78 \\
\hline
\end{tabular}


Table 3 (cont.). The Long-Term Climate Risk Index (CRI): The 10 countries most affected from 1999 to 2018 (annual averages) - (Germanwatch, 2020)

\begin{tabular}{|c|c|c|c|c|c|c|c|}
\hline $\begin{array}{c}\text { CRI 1999- } \\
2018(1998- \\
2017)\end{array}$ & Country & CRI score & Death toll & $\begin{array}{c}\text { Deaths per } \\
100000 \\
\text { inhabitants }\end{array}$ & $\begin{array}{c}\text { Total losses } \\
\text { in million } \\
\text { US\$ PPP }\end{array}$ & $\begin{array}{c}\text { Losses per } \\
\text { unit GDP in } \\
\%\end{array}$ & $\begin{array}{c}\text { Number of } \\
\text { events (total } \\
1999-2018)\end{array}$ \\
\hline $4(5)$ & Philippines & 17.67 & 869.80 & 0.96 & 3118.68 & 0.57 & 317 \\
\hline $5(8)$ & Pakistan & 28.83 & 499.45 & 0.30 & 3792.52 & 0.53 & 152 \\
\hline $6(9)$ & Vietnam & 29.83 & 285.80 & 0.33 & 2018.77 & 0.47 & 226 \\
\hline $7(7)$ & Bangladesh & 30.00 & 577.45 & 0.39 & 1686.33 & 0.41 & 191 \\
\hline $8(13)$ & Thailand & 31.00 & 140.00 & 0.21 & 7764.06 & 0.87 & 147 \\
\hline $9(11)$ & Nepal & 31.50 & 228.00 & 0.87 & 225.86 & 0.40 & 180 \\
\hline $10(10)$ & Dominica & 32.33 & 3.35 & 4.72 & 133.02 & 20.80 & 8 \\
\hline
\end{tabular}

Source: Germanwatch-Bonn (2020:9). Puerto Rico, Myanmar, and Haiti have been identified as the most affected countries57 in this twenty-year period. They are followed by the Philippines, Pakistan, and Vietnam - [Notes- Compared to the CRI 2019, which considered the period from 1998 to 201758, there have been a few changes in the CRI ranking: while Puerto Rico remains at the top of the list, Myanmar and Haiti each move up one place to become one of the three most affected countries over the past two decades. (GermanwatchBonn (2020:9)].

In terms of most affected country with the evidence of 2018, India is fifth victim country in the world context (table 4).

Table 4. Key Results of the Global Climate Risk Index 2020 (The ten most affected countries in 2018)

\begin{tabular}{|c|c|c|c|c|c|c|c|}
\hline $\begin{array}{c}\text { Ranking } \\
2017\end{array}$ & Country & CRI score & Death toll & $\begin{array}{c}\text { Deaths per } \\
100000 \\
\text { inhabitants }\end{array}$ & $\begin{array}{c}\text { Absolute } \\
\text { losses in } \\
\text { million US\$ } \\
\text { PPP }\end{array}$ & $\begin{array}{c}\text { Losses per } \\
\text { unit GDP in } \\
\%\end{array}$ & $\begin{array}{c}\text { Human } \\
\text { Development } \\
\text { Index 2018 } \\
\text { Ranking }\end{array}$ \\
\hline $1(36)$ & Japan & 5.50 & 1282 & 1.01 & 35839.34 & 0.64 & 19 \\
\hline $2(20)$ & Philippines & 11.17 & 455 & 0.43 & 4547.27 & 0.48 & 113 \\
\hline $3(40)$ & Germany & 13.83 & 1246 & 1.50 & 5038.62 & 0.12 & 5 \\
\hline $4(7)$ & Madagascar & 15.83 & 72 & 0.27 & 568.10 & 1.32 & 161 \\
\hline $5(14)$ & India & 18.17 & 2081 & 0.16 & 37807.82 & 0.36 & 130 \\
\hline $6(2)$ & Sri Lanka & 19.00 & 38 & 0.18 & 3626.72 & 1.24 & 76 \\
\hline $7(45)$ & Kenya & 19.67 & 113 & 0.24 & 708.39 & 0.40 & 142 \\
\hline $8(87)$ & Rwanda & 21.17 & 88 & 0.73 & 93.21 & 0.34 & 158 \\
\hline $9(42)$ & Canada & 21.83 & 103 & 0.28 & 2282.17 & 0.12 & \\
\hline $10(96)$ & Fiji & 22.50 & 8 & 0.90 & 118.61 & 1.14 & 12 \\
\hline
\end{tabular}

Source: Germanwatch-Bonn (2020:6). Japan, the Philippines and Germany were the most affected countries in 2018 followed by Madagascar, India, and Sri Lanka.

The yearly monsoon season, lasting from June to September, severely affected India (5) in 2018. The state of Kerala was especially impacted - 324 people died because of drowning or being buried in the landslides set off by the flooding,30 the worst in one hundred years. Over 220000 people had to leave their homes, 20000 houses and 80 dams were destroyed. The damage amounted to EUR 2.4 billion (US\$ 2.8 billion).32 Furthermore, India's east coast was hit by the cyclones Titli and Gaja in October and November 2018. With wind speeds of up to 150 kilometers per hour, cyclone Titli killed at least eight people and left around 450000 without electricity. Sri Lanka (6) started the year 2018 with severe monsoon rains from 20th to 26th May affecting 20 districts, especially the south and west coast.34The provinces of Galle and Kalutara were the most affected. In Galle, $166 \mathrm{~mm}$ of rain fell in 24 hours - usually the district has an average precipitation of $290 \mathrm{~mm}$ in the full month of May. At least 24 At least 24 people died, more than 170 000 people were affected and nearly 6000 people were displaced (Germanwatch, 2020:7).

\section{Women are the major victims of climate change impact}

In the farming practices in the world context as well as South Asian context, the women are the main sufferer of climate change. First, climate change raises the risk on food security, alters the cropping pattern, and secondly, it also plays the triggering role to widen inequality. As stated in the 52nd session of the Commission on the Status of Women (2008), Women are more vulnerable to the effects of climate change than men-primarily as they constitute the majority of 
the world's poor and are more dependent for their livelihood on natural resources that are threatened by climate change. Furthermore, they face social, economic, and political barriers that limit their coping capacity. Women and men in rural areas in developing countries are especially vulnerable when they are highly dependent on local natural resources for their livelihood. Those charged with the responsibility to secure water, food and fuel for cooking and heating face the greatest challenges. Secondly, when coupled with unequal access to resources and to decision-making processes, limited mobility places women in rural areas in a position where they are disproportionately affected by climate change. It is thus important to identify gender-sensitive strategies to respond to the environmental and humanitarian crises caused by climate change. It is important to remember, however, that women are not only vulnerable to climate change, but they are also effective actors or agents of change in relation to both mitigation and adaptation. Women often have a strong body of knowledge and expertise that can be used in climate change mitigation, disaster reduction and adaptation strategies. Furthermore, women's responsibilities in households and communities, as stewards of natural and household resources, positions them well to contribute to livelihood strategies adapted to changing environmental realities (United Nations 2008) (table 5).

\section{Table 5. The Women are in risk due to Climate Change}

\begin{tabular}{|c|c|}
\hline Area & Evidence \\
\hline $\begin{array}{l}\text { Women, Gender } \\
\text { Equality and } \\
\text { Climate Change }\end{array}$ & $\begin{array}{l}\text { Detrimental effects of climate change can be felt in the short-term through natural hazards, such as landslides, } \\
\text { floods, and hurricanes; and in the long-term, through more gradual degradation of the environment. The } \\
\text { adverse effects of these events are already felt in many areas, including in relation to, inter alia, agriculture } \\
\text { and food security; biodiversity and ecosystems; water resources; human health; human settlements and } \\
\text { migration patterns; and energy, transport, and industry. (whereas main victims are always women and } \\
\text { children). }\end{array}$ \\
\hline Food Security & $\begin{array}{l}\text { Women face loss of income as well as harvests-often their sole sources of food and income. Related } \\
\text { increases in food prices make food more inaccessible to poor people, to women and girls whose health has } \\
\text { been found to decline more than male health in times of food shortages. }\end{array}$ \\
\hline $\begin{array}{l}\text { Impact of } \\
\text { Biodiversity Loss }\end{array}$ & $\begin{array}{l}\text { In many parts of the world, deforestation has meant that wood - the most widely used solid fuel - is located } \\
\text { further away from the places where people live. In poor communities in most developing countries, women } \\
\text { and girls are responsible for collecting traditional fuels, a physically draining task that can take from } 2 \text { to } 20 \\
\text { or more hours per week. As a result, women have less time to fulfil their domestic responsibilities, earn } \\
\text { money, engage in politics or other public activities, learn to read or acquire other skills, or simply rest. Girls } \\
\text { are sometimes kept home from school to help gather fuel, perpetuating the cycle of disempowerment. }\end{array}$ \\
\hline Water Resources & $\begin{array}{l}\text { Climate change has significant impacts on fresh water sources, affecting the availability of water used for } \\
\text { domestic and productive tasks. The consequences of the increased frequency in floods and droughts are far } \\
\text { reaching, particularly for vulnerable groups, including women who are responsible for water management at } \\
\text { the household live.........Given the changing climate, inadequate access to water and poor water quality does } \\
\text { not only affect women, their responsibilities as primary givers, and the health of their families', it also } \\
\text { impacts agricultural production and the care of livestock; and increases the overall amount of labor that is } \\
\text { expended to collect, store, protect and distribute water. }\end{array}$ \\
\hline Health & $\begin{array}{l}\text { climate change scenarios include increased morbidity and mortality due to heat waves, floods, storms, fires, } \\
\text { and droughts.........floods - increasing consistently with climate change-may also increase the prevalence of } \\
\text { water-related diseases, especially water and vector-borne diseases, which affect millions of poor people each } \\
\text { year. In addition, an increase in prevalence of diseases will likely aggravate women's caregiving of family } \\
\text { and community members who are ill. }\end{array}$ \\
\hline $\begin{array}{l}\text { Human } \\
\text { Settlements and } \\
\text { Migration } \\
\text { Patterns }\end{array}$ & $\begin{array}{l}\text { Climate change adds a new complexity to the areas of human mobility and settlement by exacerbating } \\
\text { environmental degradation........the migratory consequences of environmental factors result in higher death } \\
\text { rates for women in least developed countries, as a direct link to their socioeconomic status, to behavioral } \\
\text { restrictions and poor access to information. }\end{array}$ \\
\hline $\begin{array}{l}\text { Women's Human } \\
\text { Rights }\end{array}$ & $\begin{array}{l}\text { Climate change affects the economic and social rights of countless individuals; this includes their rights to } \\
\text { food, health, and shelter. As climate change will inevitably continue to affect humanity, a key UN priority is } \\
\text { safeguarding the human rights of people whose lives are most adversely affected. }\end{array}$ \\
\hline $\begin{array}{l}\text { Women, Gender } \\
\text { Equality and } \\
\text { Energy }\end{array}$ & $\begin{array}{l}\text { Linkages between energy supplies, gender roles and climate change are strongest in countries with low } \\
\text { availability of basic electricity and modern fuels, as well as high dependence on biomass fuels for cooking, } \\
\text { heating and lighting - and close to two billion people in the developing world use traditional biomass fuels as } \\
\text { their primary source of energy. In these countries, cultural traditions make women responsible for gathering } \\
\text { fuel and providing food, even when this involves long hours performing heavy physical labor or travelling } \\
\text { longer distances. With the onslaught of aggravated environmental changes, women are likely to continue } \\
\text { spending long (perhaps even longer) hours fetching firewood, drawing water, working the land, and grinding } \\
\text { cereal crops. }\end{array}$ \\
\hline
\end{tabular}




\section{Table 5 (cont.). The Women are in risk due to Climate Change}

\begin{tabular}{|l|l|}
\hline \multicolumn{1}{|c|}{ Area } & \multicolumn{1}{c|}{ Evidence } \\
\hline $\begin{array}{l}\text { Technology is } \\
\text { Never Gender- }\end{array}$ & $\begin{array}{l}\text { Technology is never gender-neutral and when coupled with the negative effects of the changing climate, it is } \\
\text { even less gender-sensitive. In many developing countries, the access of girls and women to information and } \\
\text { communication technology is constrained by social and cultural bias, inadequate technological infrastructure } \\
\text { in rural areas, women's lower educations levels (especially in the fields of science and technology) and the } \\
\text { fear of or lack of interest in technology, and women's lack of disposable income to purchase technology } \\
\text { services }\end{array}$ \\
\hline $\begin{array}{l}\text { Vulnerability of } \\
\text { Women to }\end{array}$ & $\begin{array}{l}\text { The vulnerability of women to disasters is increased for several reasons. Post-disaster, women are usually at } \\
\text { higher risk of being placed in unsafe, overcrowded shelters, due to lack of assets, such as savings, property, } \\
\text { or land. In the context of cyclones, floods, and other disasters that require mobility, cultural constraints on } \\
\text { women's movements may hinder their timely escape, access to shelter or access to health care. }\end{array}$ \\
\hline
\end{tabular}

Source: open- UN- https://www.un.org/womenwatch (2020). These texts are adopted from https://www.un.org/womenwatch (April 5, 2021) the additional information of gender and climate change can be found in the United Nations websites. Table 5, Climate Change- role to rise inequality (Women) is self-explanatory, which gives a clear picture of how women are specially victimized due to climate change and how the climate change is playing crucial role to widen the inequality among men and women. In the farming systems, women have multiple roles and responsibilities maintaining the household to involved in each activities of farming; however, their contributions are not acknowledged equal to male partners.

Climate change has impact in every ecosystems of the world and agriculture ecosystem is more sensitive to the climatic change. As a result, the crop production pattern particularly vulnerable or risk countries of South Asia are already in the crisis. The above listed scenarios clearly indicate that, the world is witnessing the climate change impact in agriculture system globally, however, main victim of climate change are the small farmers of developing countries and women in particular. The impact depends on the risk factors (as seen in table 3 and 4). Climate Change also playing the triggering role to widen economic, and social inequality between men and women.

\section{The Coping Strategies with Climate Change}

Several academic research and reports recommend about the similar types coping strategies to the farmers and the governments (Aryal et al., 2020; Ortiz et al., 2008; Vinke et al., 2017; Sivakumar and Stefanski, 2011; FAO 2021; Pradhan et al., 2015; NSAC, 2019; Tiwari et al., 2019; Mazurek, 2021; Dickie et.al., 2014; World Bank, 2015) as shown in the table 6.

Table 6. What farmers should do to cope with changing weather pattern

\begin{tabular}{|l|l|}
\hline \multicolumn{1}{|c|}{ Author Authority } & \multicolumn{1}{c|}{ Recommendations } \\
\hline Tiwari et al. 2019 & $\begin{array}{l}\text { diversification of crop type; diversification of crop varieties; change in planting calendar; change in use of } \\
\text { chemical fertilizers; change in use of chemical pesticides; implementing soil conservation methods. } \\
\text { adopting water harvesting techniques; change in agronomic practices-mulching of soil; changing the } \\
\text { traditional irrigation method, } \\
\text { switching from mono cropping to integrated farming system } \\
\text { crop rotation; intercropping; use of soil health cards; preventing/reducing soil erosion }\end{array}$ \\
\hline $\begin{array}{l}\text { Akinnagbe } \\
\text { Irohibe 2014 and }\end{array}$ & $\begin{array}{l}\text { diversification of herds and incomes, use of forest products as a buffer against climate induced crop } \\
\text { failure, soil fertility improvement techniques, soil moisture and water conservation practices, } \\
\text { decentralization of governance of resources and the manipulation of land use leading to land use } \\
\text { conversion }\end{array}$ \\
\hline $\begin{array}{l}\text { Bhatta and Aggrawal } \\
2016\end{array}$ & $\begin{array}{l}\text { adaptive practices are changing cropping patterns and adoption of resilient crop varieties. a large number } \\
\text { of farmers place emphasis on breeding crop varieties that tolerate adverse weather. governments should } \\
\text { implement a number of planned activities to cope with adverse events, with the aim that these activities } \\
\text { would be synergistic with adaptation to climate change }\end{array}$ \\
\hline WEF 2021 & $\begin{array}{l}\text { reducing tillage, expanding crop rotations, planting cover crops and reintegrating livestock into crop } \\
\text { production system }\end{array}$ \\
\hline WRI 2021 & $\begin{array}{l}\text { pursue sustainable forestry; plant agroforestry systems; rehabilitate degraded pastures; integrate crop- } \\
\text { livestock-forestry systems }\end{array}$ \\
\hline Mazurek 2021 & $\begin{array}{l}\text { efficient irrigation management; renewable energy; organic practices; increasing soil health; keeping } \\
\text { agriculture green; reducing livestock methane emissions; pasture-based livestock management; protecting } \\
\text { farmland; supporting farmers markets and local food; pushing for climate-friendly policies }\end{array}$ \\
\hline
\end{tabular}


Table 6 (cont.). What farmers should do to cope with changing weather pattern

\begin{tabular}{|c|c|}
\hline Author Authority & Recommendations \\
\hline NSAC 2019 & $\begin{array}{l}\text { sequestering carbon through soil health improvement practices; organic farming, carbon sequestration, } \\
\text { and greenhouse gas mitigation; nutrient management to mitigate nitrous oxide emissions from soil; } \\
\text { keeping the land in grass, planting field edges and marginal lands to perennials, supporting pest control } \\
\text { and reducing surface reflections; livestock management, grazing, and crop-livestock integration; } \\
\text { composting, organic residue recycling, biochar (biochar, or "black carbon," is a soil amendment created } \\
\text { by pyrolysis (intense heating with low oxygen supply) of organic residues), and other organic } \\
\text { amendments; reducing agricultural GHGS through reduced inputs, energy conservation, and increased } \\
\text { energy efficiency; water management }\end{array}$ \\
\hline $\begin{array}{l}\text { NSAC 2019- } \\
\text { Recommendation to } \\
\text { the policy makers }\end{array}$ & $\begin{array}{l}\text { establish a monitoring, evaluation, and reporting system } \\
\text { financial support for the subsistence farmer } \\
\text { fund public plant and animal breeding for a climate-resilient agriculture } \\
\text { focus climate change research, conservation incentive programs } \\
\text { support climate-friendly nutrient management system } \\
\text { increase support for composting as a climate friendly alternative } \\
\text { support climate-friendly livestock production systems }\end{array}$ \\
\hline $\begin{array}{l}\text { Kim 2019- } \\
\text { Recommendation to } \\
\text { the policy makers }\end{array}$ & $\begin{array}{l}\text { establishment of a resource-cycling agricultural system integration of agricultural policy and low-carbon } \\
\text { eco-friendly policy } \\
\text { activation of climate smart agriculture } \\
\text { development and dissemination of low-carbon green technology } \\
\text { development of policy programs based on carbon information utilization of green finance in the } \\
\text { agricultural sector } \\
\text { education and communication for green growth }\end{array}$ \\
\hline FAO 2008 & $\begin{array}{l}\text { Improved crop and grazing land management to increase soil carbon storage; restoration of cultivated } \\
\text { peaty soils and degraded lands; improved rice cultivation techniques and livestock and manure } \\
\text { management to reduce } \mathrm{CH} 4 \text { emissions; improved nitrogen fertilizer application techniques to reduce } \mathrm{N} 2 \mathrm{O} \\
\text { emissions; dedicated energy crops to replace fossil fuel use; improved energy efficiency; mulch farming, } \\
\text { conservation tillage, cover cropping and recycling of bio-solids. } \\
\text { Financial incentives and regulations for improving land management, maintaining soil carbon content, and } \\
\text { making efficient use of fertilizers and irrigation }\end{array}$ \\
\hline World Bank 2021 & $\begin{array}{l}\text { Climate-smart agriculture (CSA) is an integrated approach to managing landscapes-cropland, livestock, } \\
\text { forests, and fisheries--that address the interlinked challenges of food security and climate change. }\end{array}$ \\
\hline $\begin{array}{l}\text { World Bank 2021- } \\
\text { Policy } \\
\text { recommendations }\end{array}$ & $\begin{array}{l}\text { climate risk cannot be reduced to zero, which means governments must take decisive action to help } \\
\text { households and businesses manage them. } \\
\text { build resilient foundations with rapid and inclusive development } \\
\text { help people and firms do their part } \\
\text { revise land use plans and protect critical infrastructure } \\
\text { help people and firms recover faster and better } \\
\text { manage impacts at the macro level } \\
\text { prioritize according to needs, implement across sectors and monitor progress }\end{array}$ \\
\hline
\end{tabular}

Source: Author compilation (from Tiwari et al. 2019; Akinnagbe and Irohibe 2014; Bhatta and Aggrawal 2016; WEF 2021; WRI 2021; Mazurek 2021; NSAC 2019; Kim 2019; FAO 2008 and World Bank 2021).

There is no doubt that each of the mitigation and adaptation as well as policy recommendations are valid, however, it is necessary to consider geographical condition (mountain, plain) of the country and what is the level of the farmer, the agriculture infrastructure (irrigated, rainfed, manual or mechanical, commercial, subsistence), the social system, community system, political system and even cultural practices related to agriculture systems. The formers of South Asian countries- Nepal, India, Bangladesh, Pakistan hold strong ties with farming system which includes livestock. Therefore, it is necessary to understand what coping strategies farmers are applying (probably the same as listed above), and what is working and what is not working. It is necessary to understand the traditional coping practices, the indigenous knowledge of both adaptation and mitigation mechanisms developed by the local farmers. "People perception and understanding of climate change can be an important asset to adaptation to climate change while it is rarely taken into consideration" (Negi et. al. 2017:415). Therefore, it is necessary to understand the varieties climate change impacts in every farming ecosystems and provide support to the needy farmers based on their necessity and demand. 


\section{Conclusion}

It is known fact that agriculture ecosystem system has been facing direct impact of climate change, as a consequences, there is a challenges of food security, the food production, distribution, and consumption system. There are noticeable changes in South Asian agricultures practices. The region is one of the most vulnerable to climate change due to its geographical structure. The climate change pattern in South Asia, shows remarkable changes, and risk in weather pattern and it has direct impact on agriculture system. The Climate Risk Index indicate the increasing high risk of unprecedented climate change shocks. The people in poverty and women are the major victims of climate change impact. To cope with climate change impact on agriculture various adaptation and mitigation mechanisms are needed.

There is no doubt that agriculture filed has been facing the climate change induced problem directly and have adverse impact. The developing world whose major economy is based on agriculture; have witnessing severe climatic variation since last decades or so. There is an assumption that farmers' livelihood depends on incomes based on the size of farmlands, number of cattle, economically active population in the family, highest level of education a family member has, involvement of a family members in various types of jobs including remittance practices, distances of settlements to nearby markets, existing forest resources in the vicinities of households, types of house, and dependency ratios (Bhandari 2018a, 2018b). However, there are no such research, which validates such assumption. There are knowledge gaps in the interrelationships of climatic factors and vulnerability to increase understanding of how the various geospatial technologies help to link between science and conscience facing the development planners, resource managers and environmental scientists working to resolve local, regional, and national ecosystem services that are representatives of other South Asian countries mainly hit by climatic variability. Researchers need to explore more on these issues in their future research.

\section{Recommendation}

The main recommendations to cope with the climate change impacts for farmers and the policy makers are listed above in table 6. "What farmers should do to cope with changing weather pattern".

The climate events will affect agricultural farming at various level. These changes impact on the ecosystem services that support growing human population. To mitigate these problems, there is research need:

1. To explore the knowhow of the food production patterns and propose alternatives to increase the productivity of healthy food even at the time of climatic variations.

2. Develop a model and replicate it, if applicable, to other areas.

3. To explore how subsistence farmers are responding to climate change and other socioeconomic factors to maintain their livelihoods in a sustainable manner.

4. To investigate whether the issues of equity especially the wellbeing of disadvantage groups are addressed by policy instruments.

5. To explore how the people are contributing to the sustainable management of natural resources and biodiversity at the time of climate variation.

There is a need of institutional architecture to deal with the climate change and its impact on agriculture. Farmers friendly programs and policies are needed. Based on research finding (farmers experiences), coping, adaptation, mitigation measures should be implemented to minimize climate change induced challenges in the agriculture systems.

\section{Funding: self-funded.}

Author contribution: conceptualization: Medani P. Bhandari; data curation: Medani P. Bhandari; formal analysis: Medani P. Bhandari; funding acquisition: Medani P. Bhandari; investigation: Medani P. Bhandari; methodology: Medani P. Bhandari; project administration Medani P. Bhandari; resources: Medani P. Bhandari; software: Medani P. Bhandari; supervision: Medani P. Bhandari; validation: Medani P. Bhandari; visualization: Medani P. Bhandari; writing - original draft: Medani P. Bhandari; writing - review \& editing: Medani P. Bhandari. 


\section{References}

1. Adger, W. N. et al. (2007). Assessment of adaptation practices, options, constraints, and capacity. In Climate Change 2007: Impacts, Adaptation and Vulnerability. Contribution of Working Group II to the Fourth Assessment Report of the IPCC, Cambridge, UK: Cambridge University Press. Available at: [Link].

2. Adhikari, Jagannath (2008). Food Crisis in Karnali: A Historical and Politico-economic Perspective. Kathmandu, Nepal: Martin Chautari. Available at: [Link].

3. Akinnagbe, O.M. and Irohibe, I.J. (2014). Agricultural Adaptation Strategies to Climate Change Impacts in Africa: A Review. Bangladesh J. Agril. Res. 39(3), 407-418. Available at: [Google Scholar], [Link].

4. Aryal, Jeetendra Prakash, Tek B. Sapkota, Ritika Khurana, Arun Khatri-Chhetri, Dil Bahadur Rahut1 and M. L. Jat (2020). Climate change and agriculture in South Asia: adaptation options in smallholder production systems. Environment, Development and Sustainability, 22, 5045-5075. Available at: [Google Scholar], [Link].

5. Associates, prepared with the support of the Climate and Land Use Alliance. Report and supplementary. Available at: [Link].

6. Axinn, W.G., and D. Ghimire (2007). Social Organization, Population, and Land Use. University of Michigan: Population Studies Center. Aailable at: [Link].

7. Bandara, J. S., \& Cai, Y. (2014). The impact of climate change on food crop productivity, food prices and food security in South Asia. Economic Analysis and Policy, 44, 451-465. Available at: [Google Scholar], [Link].

8. BBC Nepali News daily (2018). The Climate Change Impact on Agriculture, BBC, Nepali. Available at: [Link].

9. Bhandari, Medani P. (2012) Environmental Performance and Vulnerability to Climate Change: A Case Study of India, Nepal, Bangladesh, and Pakistan, "Climate Change and Disaster Risk Management" Series: Climate Change Management (pp 149-167), Springer, New York / Heidelberg. Available at: [Google Scholar], [Link].

10. Bhandari, Medani P. (2020). Getting the Climate Science Facts Right: The Role of the IPCC, River Publishers, Denmark / the Netherlands. Available at: [Google Scholar], [Link].

11. Bhatta, Gopal Datt and Pramod Kumar Aggarwal (2016) Coping with weather adversity and adaptation to climatic variability: a cross-country study of smallholder farmers in South Asia, Climate and Development, 8:2, 145-157. [CrossRef].

12. Bhattarai, K. (2010). Land ownership and the use of forest in Nepal, VDM Publishing House. Available at: [Google Scholar], [Link].

13. Brown, O. (2008). Migration and Climate Change. Geneva, Switzerland: InternationalOrganization for Migration. Available at: [Link].

14. Cai, W, Borlace, S., Lengaigne, M., Rensch, P. V., Collins, M., Vecchi, G., Timmermann, A., Santoso, A., McPhaden, M. J., Wu, L., England, M. H., Wang, G., Guilyardi, E., Jin, F. (2014). Change, 4, 111-116. Available at: [Google Scholar], [Link].

15. Carr, D. L. (2009). Population and deforestation: why rural migration matters. Progress in Human Geography 33 (3):355-378. [CrossRef].

16. CBS (1996a). Nepal Living Standards Survey Report, vol. I. Kathmandu, Nepal: Central Bureau of Statistics. Available at: [Link].

17. CBS (1996b). Nepal Living Standards Survey Report, vol. II. Kathmandu, Nepal: Central Bureau of Statistics. Available at: [Link].

18. CBS (2010). Statistical Yearbook. Central Bureau of Statistics, Government of Nepal, Kathmandu, Nepal. Available at: [Link].

19. Chhetri, N.B. (2008). Understanding the Process of Agricultural Adaptation to Climate Change: Analysis of Climate-Induced Innovation in Rice Based Cropping System of Nepal. Laxenburg, Austria: IIASA Interim Report October 2008. Available at: [Google Scholar], [Link].

20. Cruz, R.V., Harasawa, H., Lal, M., Wu, S., Anokhin, Y., Punsalmaa, B., Honda, Y., Jafari, M., Li, C., Huu, N. (2007). Asia. Climate change, 2007, impacts, adaptation, and vulnerability. In: Parry, M.L., Canziani, O.F., Palutikof, J.P. et al. (eds.). Contribution of Working Group II to the Fourth Assessment Report of the 
Intergovernmental Panel on Climate Change. Cambridge University Press, Cambridge, pp 469-506. Available at: [Link].

21. Dickie, A., Streck, C., Roe, S., Zurek, M., Haupt, F., Dolginow, A. (2014). Strategies for Mitigating Climate Change in Agriculture: Abridged Report. Available at: [Link].

22. FAO (2008). Climate Change Adaptation and Mitigation in The Food And Agriculture Sector, FAO, Rome. Available at: [Link].

23. FAO (2015). Climate Change and Food Security: Risks and Responses, FAO, Rome. Available at: [Link].

24. FAO (2019). FAO's Work on Climate Change, United Nations, Climate Change, FAO, Rome. Available at: [Link].

25. FAO (2021). The impact of disasters and crises on agriculture and food security: 2021. Rome. Available at: [Link].

26. Feleke, S., Kilmer, R., and Gladwin, C. (2005). Determinants of food security in Southern Ethiopia at the household level. Agricultural Economics, 33, 351-363. Available at: [Google Scholar], [Link].

27. Germanwatch (2020). Global Climate Risk Index 2020, Germany. Available at: [Google Scholar], [Link].

28. Ghale, Y. (2010). Right to food and food security in the changing context. Pyakuryal, P. N. and B. R. Upreti (eds). Land Agriculture and Agrarian Transformation. Consortium for Land Research and Policy Dialogue (COLARP). Available at: [Link] (retrieved 6/8/2018)

29. Ghimire, A. and B. R. Upreti (2010). The forgotten forces: Role of migrants in post-conflict Nepal. In Upreti, B. R., S. R. Sharma, K. N. Pyakuryal, and S. Ghale (eds.). The Remake of a State: Post- Conflict Challenges and State Building in Nepal. South Asia Regional Coordination Office of the Swiss National center of Competence in Research (NCCR North-South) and Human and Nature Resources Studies Centre, Kathmandu University, Nepal. Available at: [Link].

30. Global Food Security Program. (2015). Extreme weather and resilience of the global food system. FAO, Rome. Available at: [Link].

31. Huddleston, B., E. Ataman, P. De Salvo, M. Zanetti, M. Bloise, J. Bel, G. Francheschini, and L. Fed'Ostiani, (2003). Towards a GIS-Based Analysis of Mountain Environments and Populations. Food and Agriculture Organization of the United Nations, Rome, Italy. Available at: [Link].

32. IPCC (1990). The Potential Impacts of Climate Change: Impacts on Agriculture and Forestry, IPCC, Geneva. Available at: [Link].

33. IPCC (2007). Climate Change 2007: the physical science basis. In: Solomon, S., Quin, D., Manning, M., Chen, X., Marquis, M., Averyt, K.B., Tignor, H.L., Miller, M. (eds.). Contribution of Working Group I to the Fourth Assessment Report of the IPCC, Cambridge University Press, Cambridge, pp 1-996. Available at: [Link].

34. IPCC (2014). Summary for policymakers. In: Climate Change 2014: Impacts, Adaptation, and Vulnerability. Part A: Global and Sectoral Aspects. Contribution of Working Group II to the Fifth Assessment Report of the IPCC, Geneva. Available at: [Link].

35. IPCC (2018). IPCC Chapter 3: Impacts of $1.5^{\circ} \mathrm{C}$ global warming on natural and human systems. In: Global Warming of $1.5 \quad{ }^{\circ} \mathrm{C}$. Special Report of the IPCC, Geneva. https://www.ipcc.ch/site/assets/uploads/sites/2/2019/03/SR15 FGD Chapter 3.pdf

36. Kim, Chang-Gil (2019). Low Carbon Green Growth Roadmap for Asia and the Pacific, The Impact of Climate Change on the Agricultural Sector: Implications of the Agro-Industry for Low Carbon, Green Growth Strategy and Roadmap for the East Asian Region, Korea International Cooperation Agency (KOICA), South Korea. Available at: [Link].

37. Mazurek, Brie (2021). CUESA Organization. San Francisco, CA. Available at: [Link].

38. Nagi, Chanana N., Aggarwal, P.K. (2020). Woman in agriculture, and climate risks: hotspots for development. Climatic Change, 158, 13-27. [CrossRef].

39. NSAC (2019). Agriculture and Climate Change: Policy Imperatives and Opportunities to Help Producers Meet the Challenge. National Sustainable Agriculture Coalition. Washington D.C. Available at: [Link].

40. Ortiz, R., Sayre, K. D., Govaerts, B., Gupta, R., Subbarao, G., Ban, T., et al. (2008). Climate change: Can wheat beat the heat? Agriculture, Ecosystems and Environment, 126, 46-58. [CrossRef]. 
41. Pandey, Vijay Laxmi, S. Mahendra Dev, Usha Jayachandran (2016). Impact of agricultural interventions on the nutritional status in South Asia: A review. Food Policy, 62, 28-40. Available at: [Google Scholar], [Link].

42. Parry, M., Arnell, N., Berry, P., Dodman, D., Fankhauser, S., et. al. (2009). Report on Reports: adaptation to climate change: assessing the costs. Environment: Science and Policy for Sustainable Development, 51, 2936. [CrossRef].

43. Parry, M.L. (1990). Climate change and world agriculture. Earthscan Publications Ltd, London. On potential impacts on agriculture: See Parry, M.L., Carter, T.R. and Konijn, N.T. (1988 eds.). The Impact of Climatic Variations on Agriculture, Volume 1, Assessments in Cool Temperate and Cold Regions. Volume 2, Assessments in Semi-Arid Regions (Dordrecht, The Netherlands: Kluwer). Available at: [Link].

44. Petit, J.R., Jouzel, J., Raynaud, D., Barkov, N.I., Barnola, J.M., Basile, I., Bender, M., Chappellaz, J., Davis, M., Delaygue, G., Delmotte, M., Kotlyakov, V.M., Legrand, M., Lipenkov, V.Y., Lorius, C., Pépin, L., Ritz, C., Saltzman, E., Stievenard, M. (1999). Climate and atmospheric history of the past 420,000 years from the Vostok ice core, Antarctica. Nature, 399, 429-436. Available at: [Link].

45. Pradhan, Neera Shrestha, Suman Sijapati \& Sagar Ratna Bajracharya (2015). Farmers' responses to climate change impact on water availability: insights from the Indrawati Basin in Nepal. International Journal of Water Resources Development, 31(2), 269-283. [CrossRef].

46. Pyakuryal, B., Roy, D. and Thapa, Y. B. (2010). Trade liberalization and food security in Nepal. Food Policy, 35(1), 20-31. [CrossRef].

47. Pyakuryal, P. N. and B. R. Upreti (2010) (eds). Land Agriculture and Agrarian Transformation. Consortium for Land Research and Policy Dialogue (COLARP), Nepal. Available at: [Google Scholar], [CrossRef].

48. Rasul, G., Saboor, A., Tiwari, P.C., Hussain, A., Ghosh, N. and Chettri, G.B. (2019). Food and nutritional security in the Hindu Kush Himalaya: Unique challenges and niche opportunities. In: The Hindu Kush Himalaya Assessment: Mountains, Climate Change, Sustainability and People in P. Wester, A. Mishra, A. Mukherji, and A.B. Shrestha, (eds.). Springer Netherlands, Dordrecht, Netherlands, pp. 627. Available at: [Google Scholar], [Link].

49. Schmidhuber, J., \& Tubiello, F. N. (2007). Global food security under climate change. Proceedings of the National Academy of Sciences, 104, 19703-19708. Available at: [Google Scholar], [Link].

50. Shakya, S., Gyawali, D.R., Gurung, J.K. \& Regmi, P.P. (2013). A trailblazer in adopting climate smart practices: One cooperative's success story. Available at: [Google Scholar], [Link].

51. Shrestha, N. R. and K. Bhattarai (2003). Historical Dictionary of Nepal, The Scarecrow Press, Inc. Available at: [Link].

52. Shrestha, R.P., and N. Nepal, (2016). An assessment by subsistence farmers of the risks to food security attributable to climate change in Makwanpur Nepal. Food Secur., 8, 415-425. Available at: [Google Scholar], [Link].

53. Sivakumar, M.V.K. and Stefanski, R. (2011). Climate Change in South Asia, in R. Lal et al. (eds.). Climate Change and Food Security in South Asia. Available at: [Link].

54. Tewari, Poonam, Pratibha Singh and Deepika Verma (2019). A study on awareness of farm women regarding climate change and its coping strategies. International Journal of Home Science, 5(3), 150-153. Available at: [Google Scholar], [Link].

55. Thapa, Y. B. (2010). Political economy of conflict and agrarian change in Nepal. In Pyakuryal, P. N. and B. R. Upreti (2010) (eds). Land Agriculture and Agrarian Transformation. Consortium for Land Research and Policy Dialogue (COLARP). Available at: [Link].

56. The Consultative Group on International Agricultural Research-CGIAR (2011). CRP7 Proposal: Climate Change, Agriculture and Food Security (CCAFS), Lead Center: International Center for Tropical Agriculture (CIAT), Headquarters, Cali, Colombia. Available at: [Link].

57. Tiwari, P.C., and B. Joshi, (2012). Natural and socio-economic factors affecting food security in the Himalayas. Food Secur., 4, 195-207. Available at: [Link], [CrossRef].

58. Tubiello, F.N. (2005). Climate variability and agriculture: perspectives on current and future challenges. In: Knight, B. (ed.). Impact of climate change, variability and weather fluctuations on crops and their produce markets. Impact Reports, Cambridge, UK, pp 45-63. Available at: [Link]. 
59. UN Women. (2020). From Insights to Action: Gender equality in the wake of COVID-19. Available at: [Link].

60. UNEP. (2016). The Adaptation Finance Gap Report. Available at: Available at: [Link]. (16 November 2019).

61. UNEP. (2018). Human Development Indices and Indicators 2018 Statistical Update. Available at: [Google Scholar] (16 November 2019).

62. UNEP. (2019). Frontiers 2018/19. Emerging Issues of Environmental Concern. United Nations Environment Programme: Nairobi. Available at: [Link].

63. UNFCCC. (2007). Climate Change: Impacts, Vulnerabilities and Adaptation in Developing Countries. Available at: [Link] (24 November 2019).

64. UNICEF. (2018). Kenya Humanitarian Situation Report. Available at: [Link] (07 November 2019).

65. United Nations (2015). 70 years, 70 documents. Available at: [Link] (September 21, 2020).

66. United Nations (2015). Resolution Transforming our world: the 2030 Agenda for Sustainable Development. Available at: [Link] (November 5, 2020).

67. Upreti, B.R., S. R. Sharma, K.N. Pyakuryal, and Ghimire, S. (2010). The Remake of a State: Post- Conflict Challenges and State Building in Nepal. South Asia Regional Coordination Office of the Swiss National center of Competence in Research (NCCR North-South) and Human and Nature Resources Studies Centre, Kathmandu University, Nepal. Available at: [Google Scholar], [Link].

68. Vinke, K., Martin, M. A., Adams, S., Baarsch, F., Bondeau, A., Coumou, D., et al. (2017). Climatic risks and impacts in South Asia: Extremes of water scarcity and excess. Regional Environmental Change, 17, 15691583. Available at: [Link].

69. WDI, (2014). Washington. World Bank, DC. [CrossRef].

70. WEF (2021). Here's how we can use agriculture to fight climate change, 2021 World Economic Forum. Available at: [Link].

71. WFP and FAO. (2007). Food and Agricultural Markets in Nepal. Final Report, Katmandu. Available at: [Link].

72. WMO. (2017). (Un)natural Disasters: Communicating Linkages Between Extreme Events and Climate Change. Available at: [Link] (16 November 2019).

73. World Bank Data (2011). Multi scale data portal, World Bank, Washington, DC. Available at: [Google Scholar], [Link].

74. World Bank. (2015). Agricultural Risk Management in the Face of Climate Change. Washington, DC. Available at: [Link].

75. World Bank (2020). The Adaptation Principles: 6 Ways to Build Resilience to Climate Change, World Bank, Washington, DC. Available at: [Link].

76. WRI (2019). Ways Farmers Can Adapt to Climate Change and Generate Income, World Resources Institute, Washington DC. Available at: [Google Scholar], [Link]. 